Review Article

Open Access

\title{
Medicinal properties of Carica papaya Linn: Review
}

\author{
Sagadevan $\mathbf{P}^{1 *}$, Selvakumar $\mathrm{S}^{2}$, Raghunath $\mathbf{M}^{1}$, Megala $\mathbf{R}^{1}$, Janarthanan $\mathbf{P}^{3}$, Vinitha Ebziba $\mathbf{C}^{1}$ and Senthil Kumar $\mathbf{V}^{4}$ \\ ${ }^{\prime}$ Department of Biotechnology, KSG College of Arts and Science, Coimbatore, Tamilnadu, India \\ 2Department of Biotechnology, Karpagam Academy of Higher Education, Coimbatore, Tamilnadu, India \\ ${ }^{3}$ Aviagen lab udumalpet, Coimbatore, Tamilnadu, India \\ ${ }^{4}$ Department of Biotechnology, Palanisamy College of Arts, Erode, Tamilnadu, India
}

\section{Article Info}

\section{*Corresponding author:}

Sagadevan $\mathbf{P}$

Department of Biotechnology

KSG College of Arts and Science

Coimbatore, Tamilnadu

India

E-mail: sagadevan.biotech@gmail.com

Received: April 28, 2019

Accepted: September 16, 2019

Published: September 23, 2019

Citation: Sagadevan P, Selvakumar S, Raghunath $\mathrm{M}$, et al. Medicinal properties of Carica papaya Linn: Review. Madridge J Nov Drug Res. 2019; 3(1): 120-125.

doi: 10.18689/mjndr-1000118

Copyright: @ $₫ 2019$ The Author(s). This work is licensed under a Creative Commons Attribution 4.0 International License, which permits unrestricted use, distribution, and reproduction in any medium, provided the original work is properly cited.

Published by Madridge Publishers

\begin{abstract}
Medicinal properties of plants derivatives from natural products have wide range of pharmacological significance. The properties of papaya (Carica papaya) fruit and other plant parts are well known in traditional system of medicine and also known for food and nutritional values throughout the world. During the most recent decades significant advancement has been accomplished in regards to the biological activity and medicinal use of papaya, additionally, it is considered as profitable nutraceutical natural product plant. In this current review discussed with medicinal properties of $C$. papaya.
\end{abstract}

Keywords: Carica papaya; Nutraceutical; Anti-dengue activity; Anti-malarial activity; Anti-cancer activity.

\section{Introduction}

Gift of nature is medicinal plants to provide disease-free healthy life as they play an important role in protective health. Plants have numerous secondary compounds as drug for animal for a number of years. World's cultures have broad information of natural medicine, today. Traditional medicine depends on convictions and practices which existed before the improvement of "modern medicine" or "scientific drug therapy", this practice are part of our country's cultural heritage [1].

In India covered by tropic and sub-tropic regions that become the main source of aromatic and medicinal plants (AMPs) biodiversity to creates solid establishment foundation in traditional medicine. Right now utilization of plant products like leaf, flower and root are on the rise due to their easy availability, high pharmacokinetic significance and large-scale production [2].

Natural products and naturally derived components from plants have been applied in controlling toxicity, food prevention from spoilage and deterioration, furthermore broadening the time span of usability of foods. Significance of AMPs extracts used for nutraceutical, therapeutic, and cosmetic benefits, and have been demonstrated everywhere throughout the world for quite a long time. However, is the purpose why they are liable to intense interest for all nations. Therefore, quality and quantity are primordial for large commercialization of these products in World's market [3-5].

One of the major fruit crops is papaya, Carica papaya (C. papaya) L., cultivated in globally, according to FAO 2004, more than 6.8 million tones of fruit were produced in worldwide at 2004 in 389990 ha [6]. In Asian countries peoples cook green fruits, leaves, young shoots and flowers of the papaya as vegetables [7] and grind dried papaya seeds are used as pepper (Papaya Australia, 2007). Although, it is mainly grown (more than 90\%) and used as nourishment in developing and developed countries, and also it contains numerous medicinal properties. 
Papain, a proteolytic enzyme that is a component of the milky papaya latex, has many important pharmaceutical and industrial applications [8]. It is used in food biotechnology to produce chewing gums and dehydrated pulses and beans, for chill-proofing beer and tenderising meat, and in the textile industry for degumming silk and softening wool. Papain has also been employed as a component of soap, shampoo, toothpaste and skincare products The medical applications of papain include its use in US FDA-approved topical preparations as an enzymatic debridement for necrotic tissue in burns, ulcers and other wounds [9] and the preparation of vaccines and drugs for various digestive ailments. In this review work revealed the medicinal properties of $C$. papaya.

\section{Medicinal properties of $C$. papaya}

Different parts of C. papaya, including its leaves, bark, roots, latex, fruit, flowers and seeds, have a wide range of reputed medicinal applications, mostly used in traditional medicine. In Jamaica, traditionally used C. papaya ripened fruits for topical ulcer dressing to promote desloughing, granulation, healing, and reducing odour in chronic skin ulcers [10]. The green fruit is used for contraceptive purposes by traditional healers in Pakistan, India and Sri Lanka, and for various human and veterinary diseases, such as malaria, hypertension, diabetes mellitus, jaundice and intestinal helminthiasis in Nigeria [11]. The leaves have been used to treat asthma, colic, fever and beriberi (thiamine deficiency) in India [12,13)]; malaria and dengue fever in Sri Lanka, Pakistan and Malaysia [14,15]; and cancer in Vietnam and Australia [16]. The milky juice (latex) is employed as styptic and debridement when applied externally to burns and scalds [17]. People in Laos, Cambodia and Vietnam use latex to treat eczema and psoriasis [18]. The seeds have been used as a vermin fugue, thirst quencher and pain alleviator [19].

\section{Papain}

Papain plays an important role in biological processes in all living organisms. Papain, also called as papaya proteinase $\mathrm{I}$, is a cysteine protease enzyme present in papaya. It illustrates extensive proteolytic activity towards proteins, short chain polypeptides, amino acid ester and amide links, moreover it is broadly applied in food and medicine field. It preferentially cleaves peptide bonds involving basic amino acids. And also it is single chain globular protein (23406 DA) consists of 212 amino acids with four disulphide bridges. Moreover, it is active and stable underneath a wide range of conditions [20].

\section{Phytochemical Analysis}

Phytochemicals are non-nutritive plant secondary chemicals compound that have ability to production or preventing disease. Plant phytochemicals are divided into two main groups (i) primary and (ii) secondary metabolites; regarding for that functions in plant metabolism, primary metabolites comprise common sugars, amino acids, proteins and chlorophyll, while secondary metabolites consist of alkaloids, flavonoids and tannins [21]. These organic chemical substances are stored in adult cells of different tissues, such as roots, stems, leaves, flowers, fruits and seeds [22].

Alkaloids are one of the most significant compounds to discover the valuable drugs and they have a physiological effect on animals [23]. Phenolic compounds are considered as inhibitor for the growth of pathogen and also it is distributed over the plant kingdom. Potential bioactive compound tannins found in C. papaya plant, plant parts are used in food products for therapeutic purpose and also act as a precursor for drugs synthesis. The oxidation inhibiting activity of tannins contains gallic and diagallic have been known for a long time and is assumed due to the presence of gallic and diagallic acids. Saponins are glycoside compounds which have been detected in over seventy families of plants. Some of its flavones act as allele chemicals widely used in insecticides. They might also play an important role in plant disease resistance [24].

C. papaya seed extract showed bacteriostatic activity against many enteropathogens such as Bacillus subtilis, Enterobacter cloacae, Escherichia coli, Salmonella typhi, Proteas vulgaris, Pseudomonas aeruginosa and Klebsiella pneumonia. Moreover, gram-negative bacteria showed more susceptible to the extract [25-27].

Papaya and fluconazole latex has synergistic activity on growth inhibition of Candida albicans, this synergistic impact results in fractional cell wall debasement because of absence of polysaccharides constituents in fungal cell wall. Latex proteins are responsible for fungicidal action and minimum protein concentration for producing a complete inhibition at $138 \mathrm{mg} / \mathrm{dl}[28]$.

\section{Antioxidant Properties}

Free radicals are also known as "reactive oxygen species" (ROS), presence of unpaired electrons. Since electrons have stronger tendency to exist paired to unpaired state, free radicals indiscriminately pick up electrons from other atoms and converting other atoms into secondary free radicals and also thus setting up a chain reaction that can cause biological damage. From the damaging action of free radicals, our system uses substances called antioxidants, which are referred to as free radical scavenger [29].

Oxygen is essential for aerobic life process; however, cells under aerobic condition are threatened with the result of reactive oxygen metabolism (ROM) that are efficiently taken care by the powerful antioxidant system in the human body. Aerobic life is characterized by the continuous production of oxidants [30]. A shift of the balance on the antioxidant side may trigger a cascade of reaction leading to the formation of highly reactive cytotoxic compounds such as reactive oxygen metabolism [31].

Oxidative stress is defined as the state in which the level of toxic reactive oxygen intermediates (ROI) overcomes the endogenous antioxidant defence of the host. Over free radicals reacts with cellular lipids, proteins and nucleic acids, it leads to local injury and organ dysfunctions [32]. In a living system, lipid peroxidation is induced by free radicals and reactive oxygen species, which ultimately damage cells [33]. 
The widespread use of traditional herbs and medicinal plants has been traced to the occurrence of natural products with medicinal properties. As plants produce amount of antioxidants to anticipate the oxidative stress caused by photons and oxygen, they represent a potential source of new compounds with antioxidant activity [34]. Antioxidant compounds importance is understand recently because of their ability to neutralize free radicals [35]. It has been suggested that the digestion of antioxidants inhibit the free radical production and may prevent the harmful effect.

Antioxidants are radical scavengers which protect the human body against free radicals that may cause pathological conditions such as ischemia, asthma, arthritis, inflammation, neurodegeneration, Parkinson's diseases, mongolism, the ageing process and perhaps dementias [36-38]. Carotenoids, flavonoids, folic acid, ascorbic acid and tocopherol are among the antioxidants produced by plants for their substance. These antioxidants are polyphenol compounds found in all plants [38].

\section{Pharmacological Activity}

Scientific studies have been undertaken to validate the traditional uses of different parts of papaya, and have shown that C. papaya possesses antihelminthic, anti-protozoan, antibacterial, antifungal, anti-viral, anti-inflammatory, antihypertensive, hypoglycaemic and hypolipidaemic, wound healing, free radical scavenging, anti-sickling, neuroprotective, diuretic, abortifacient and antifertility properties.

Antibacterial activity found in papaya seed extracts against B. cereus, E. coli, S. faecalis, S. aureus, P. vulgaris and $S$. Flexneri [39]. Similarly, Ranajit Sen reported that bacteriostatic property of papaya seeds and pulp against from several enteropathogens, such as B. subtilis, E. cloacae, E. coli, S. typhi, S. aureus, P. vulgaris, P. aeruginosa and K. pneumonia and also found maximum inhibition zone $(15.0 \mathrm{~mm})$, additionally, superoxide and anti-oxidative activity also reported [40]. Ray and Husain demonstrated that anti-fungal activity against Candida albicans by papaya latex shows $60 \%$ of inhibitory effect against fungal pathogen [41].

Benzyl isothiocyanate is a main compound for papaya seeds having anthelminthic properties was found [42]. Airdried papaya seeds had shown a significant effect in the treatment of human intestinal parasites without side effects when the stool clearance rate for the various types of parasites was between $71.4 \%$ and $100 \%$. Further, the efficacy of papaya latex and cysteine proteinases from papaya against the gastrointestinal nematode Heligmosomoides polygyrus was suggested for a novel class of anthelmintics [43]. C. papaya seed extracts administered orally was found to induce a reversible contraceptive effect in male rats, rabbits and langur monkeys [44-46]. The antifertility effect was explained by degeneration of the germinal epithelium and germ cells, and reduction in the number of Leydig cells with the presence of vacuoles in the tubules or by changes in the plasma membrane of the head and mid-piece of human spermatozoa, leading to a total inhibition of in vitro motility [47].

\section{Wound Healing Activity}

Analogous factor may be present in latex coagulation in papaya and the mammalian coagulation. On the off chance that putative analogies do happen, it is conceivable that some plant metabolites interceding during plant healing may likewise ensuring clot formation in mammals during the healing process. The proliferative impact of papain achieved more than $15 \%$ in control, suggests properly specific proteolytic enzymes. Likewise, Chen et al. reported that papain from C. papaya latex was effective in protecting histamine-induced ulcer in the rat by blocking the acid secretion [7].

Papaya latex contains papain as a major component and nonspecific cysteine proteinase which is able to break a wide variety of necrotic tissue at $\mathrm{pH}$ 3.0-12.0. This factor may likewise have contributed towards brisk wound healing and encouraged by the activity proteinases. Papain also is known to be effective in sloughing necrotic cell, antimicrobial and antioxidant properties associated to hydroxyl scavenging and iron chelating properties. Moreover, they decrease oxidative tissue damage; likewise, they show burn healing properties as the increment in hydroxyproline content [48].

\section{Anticancer Activity}

Cell growth and cell multiplication processes are called as cell division. It must be enormously controlled that every one of the cells in the body ought to develop at the perfect place, and for every one of the organs and tissues to work appropriately. At the point when a cell divides, it first makes a precise of its DNA by means of a procedure called DNA replication, before splitting into half, to frame two 'sister' cells, which are hereditarily identical. Moreover, numerous proteins are involved in the cell division. Uncontrolled cell division may have numerous causes, to make any type of cell. Be that as it may, typically results from defects or damage from more than one gene associated with cell division. However, defected cells divided multiply to form a bulge of unusual tissue called tumour [49].

Cancer was regarded as a disease that began locally and spread progressively to other part of the tissue. Moreover, cancer cell stimulates embryonic cell in many ways and again differ from a normal cell. While embryonic cells stop proliferating and mature into adult tissue, the cancer cells just keep dividing [50]. Oxidative damage is one of the major causes of cancer induction. A free radical is a molecule with an unpaired electron. The molecule, which loses an electron, becomes free radicals giving rise to a safely perpetuating chain system.

Cancer treatment is generally a combination of few distinct modalities. On the off chance that the tumour is removed by surgery, then surgery is the single most effective tool in the anticancer armamentarium. Targeted radiotherapy is another option as with combinations of anticancer drugs. Further most of the conventional anticancer drugs have been designed with combination of deoxyribonucleic acid (DNA) 
synthesis as their target. Therein lies the problem, in that tumour cells are not the only proliferating cells in the body; patients with cancer receiving chemotherapy commonly suffer unwanted (hair loss) and sometimes potentially lifethreatening (anaemia and proneness to infections) side effects that limit treatment. Localized tumours can be removed by surgery or irradiation with high survival rates. Therefore, high death rate associated with cancer and serious side effects of chemotherapy and radiation therapy, so, many cancer patients seek alternative and complementary methods of treatment [51].

Alternative treatment of herbal therapy was introduced against for cancer, as an early more than 3,000 years ago; Chinese doctors are used herbs for cancer treatment of patients. In India, Ayurveda herbal medicine system was followed till date for anticancer treatment. Recently, numbers of herbal databases were provided information about herbal anticancer compounds. The WHO estimates that around $80 \%$ of the world's inhabitants rely on traditional medicine for their primary health care. Likewise, National Cancer Institute $(\mathrm{NCl})$ collected more than 35,000 plant samples from 20 different countries and has screened approximately 114,000 extracts for anticancer activity. From this screening couple of important anticancer compounds available today, namely taxol and camptothecin.

In vivo and limited in vitro studies have been completed, to date, to evaluate the effects of papaya extracts on cancer. However, despite these limited data, via indirect means, several studies have claimed health benefits of $C$. papaya, including against cancer and antioxidant properties. There is continuous debate regarding high antioxidant activity and anticancer activity, moreover no conclusive proof has been presented thus far. Therefore, further investigations have required assessing the putative anticancer effects and antioxidant properties of the bioactive compounds in papaya.

The effects of papaya flesh extracts on the viability of breast cancer cell line MCF-7 were examined concurrently. From studies, the authors also evaluated antioxidants in the fruits, such as $\beta$-carotene, polyphenols and flavonoids. GarciaSolis et al. [52] reported that only papaya had a significant inhibitory effect on breast cancer cell growth. Interestingly, they found that the anti-proliferative effect in cancer cells did not correlate with the total phenolic content or antioxidant activity of the fruit extracts. Additionally, an ethanolic extract from papaya pericarp inhibited cancer cell growth and scavenged nitric oxide (around 35\% for $640 \mu \mathrm{g} / \mathrm{mL}$ ) [53].

Cytotoxicity in breast cancer cell line (T47D) by ribosomeinactivating proteins isolated from C. papaya leaves, with $\mathrm{IC}_{50}$ of $2.8 \mathrm{mg} / \mathrm{mL}$. Moreover immunocytochemistry shows the induction of apoptosis via the mitochondrial pathway: in breast cancer cells treated with the protein fraction, expression of the tumour suppressor gene p53, increased by around $59.4 \%$ and also anti-apoptotic factor $\mathrm{BCl}-2$ protein expression was decreased by around $63 \%$ in comparison to the control [54].

Papaya leaf aqueous extract $(0.625-20 \mathrm{mg} / \mathrm{mL})$ affect the growth of different tumour cell lines, including solid tumour and haematopoietic cell lines. Moreover, author found that the proliferation of those cell lines was inhibited with no statistical difference between solid and haematopoietic tumour cell lines and proposed the induction of apoptosis as one of the mechanisms involved in the growth inhibitory activity. In addition to this antitumour effect, the authors also reported the ability of papaya extract to increase the production of Th1 type cytokines, such as the interleukins IL-12p40 and IL-12p70, interferon (IFN- $\gamma$ ) and tumour necrosis factor (TNF- $\alpha$ ), as well as the expression of 23 immunomodulatory genes in peripheral blood mononuclear cells.

Recently, researchers group from New South Wales, Australia, optimized the extraction conditions by using response surface methodology to obtain saponin-enriched water and ethanolic papaya leaf extracts. And also assessed the cytotoxic effect of those extracts on pancreatic cancer cells derived from both primary and metastatic sites. Ethanolic extracts with a higher level of saponins were found to be more effective in inhibiting the proliferation of two pancreatic cancer cell lines. The correlation between saponin concentration and the activity suggested that further studies be undertaken to isolate individual saponins and characterise their bioactivity.

From, beginning of human civilization, medicinal plants are used by mankind for its medicinal value. Nature is wonderful source for medicinal agents and identified from thousands of years, additionally an impressive number of modern drugs have been isolated from natural sources. An ayurvedic medicine, such as Charaka Samhita and Susruta Samhita referred for the use of more than 700 herbs. Several traditional medical systems present in India, such as Ayurveda and Unani, which has survived more than 3000 years, mainly using herbal drugs. The book of Materia Medica explained heritage of indigenous herbal practices that helped to sustain the health of peoples in India [55].

\section{Conclusion}

Papaya (Carica papaya Linn.) is well known for its excellent and medicinal properties throughout the world. In traditional medicine used papaya plant including leaves, seeds, ripe, unripe fruits and their juices, widely. Present report does not reveal any adverse/toxic effects on consumption of papaya. Significant work has been done on the biological activity and consequently broad examination on its pharmacodynamics, kinetics and proper standardization and also clinical trials are needed to explore the therapeutic application against various diseases.

\section{References}

1. Ahmad N, Fazal H, Ayaz M, Abbasi BH, Mohammad I, Fazal L. Dengue fever treatment with Carica papaya leaves extracts. Asian Pac J Trop Biomed. 2011; 1(4): 330-333. doi: 10.1016/S2221-1691(11)60055-5

2. Matkowski A, Tasarz P, Szypuła E. Antioxidant activity of herb extracts from five medicinal plants from Lamiaceae, subfamily Lamioideae. J Med Plant Res. 2008; 2(11): 321-330.

3. Amenta R, Camarda L, Di Stefano V, Lentini F, Venza F. Traditional medicine as a source of new therapeutic agents against psoriasis Fitoterapia. 2000; 71: S13-S20. 
4. Amri E, Mamboya F. Papain, a plant enzyme of biological importance: a review. Am J Biochem Biotechnol. 2012; 8(2): 99-104. doi: 10.3844/ ajbbsp.2012.99.104

5. Azarkan M, Wintjens R, Looze $Y$, Baeyens-Volant D. Detection of three wound-induced proteins in papaya latex. Phytochemistry. 2004; 65(5): 525-534. doi: 10.1016/j.phytochem.2003.12.006

6. Batra S, Kumar R, Kapoor AK, Ray G. Alteration in antioxidant status during neonatal sepsis. Ann Trop Paediatr. 2000; 20(1): 27-33.

7. Chen CF Chen SM, Chow SY, Han PW. Protective effect of Carica papaya Linn on exogenous gastric ulcer in rats. Am J Chin Med. 1981; 9(3): 205-212.

8. Duru CM, Onyedineke NE. In vitro antimicrobial assay and phytochemical analysis of ethanolic extracts of Voacanga africana seeds. J Am Sci. 2010; 6(6): 119-122.

9. Cragg GM, Newman DJ, Snader KM. Natural products in drug discovery and development. J Nat Prod. 1997; 60(1): 52-60. doi: 10.1021/np9604893

10. Dawkins $G$, Hewitt $H$, Wint $Y$, Obiefuna PC, Wint B. Antibacterial effects of Carica papaya fruit on common wound organisms. West Indian Med J. 2003; 52(4): 290-292.

11. Dhanamani M, Lakshmi Devi S, Kannan S. Ethnomedicinal plants for cancer therapy - a review. Hygeia J D Med. 2011; 3(1): 1-10.

12. Doughari $\mathrm{JH}$, Elmahmood AM, Manzara S. Studies on the antibacterial activity of root extracts of Carica papaya L. Afr J Microbiol Res. 2007: 37-41.

13. Edeoga HO, Eriata DO. Alkaloid, tannin and saponin contents of some Nigeria medicinal plants. Journal of Medicinal and Aromatic Plant Sciences. 2001; 23(3): 344-349.

14. Emeruwa AC. Antibacterial Substance from Carica papaya Fruit Extract. $J$ Nat Prod. 1982; 45(2): 123-127. doi: 10.1021/np50020a002

15. Erasto $P, G$ riersonDS, AfolayanAJ.Antioxidant constituents invernoniaamygdalina leaves. Pharm Biol. 2007; 45(3): 195-199. doi: 10.1080/13880200701213070

16. Kanatiwela de Silva C, Gammulle A, Ratnasooriya WD, Jayakody JRAC, Fernando CA, Udagama PV. Thrombocytosis and Anti-inflammatory Properties, and Toxicological Evaluation of Carica papaya Mature Leaf Concentrate in a Murine Model. Online Int J Med Plants Res. 2012; 1(2): 21-30.

17. Giordani R, Gachon C, Moulin-Traffort J, Régli P. A synergistic effect of Carica papaya latex sap and fluconazole on Candida albicans growth. Mycoses. 1997; 40(11-12): 429-437.

18. Gomes MT, Mello VJ, Rodrigues KC, et al. Isolation of two plant proteinases in latex from Carica candamarcensis acting as mitogens for mammalian cells. Planta Med. 2005; 71(3): 244-248. doi: 10.1055/s-2005-837824

19. Gupta R, Sharma AK, Dobhal MP, Sharma MC, Gupta RS. Antidiabetic and antioxidant potential of $\beta$-sitosterol in streptozotocin-induced experimental hyperglycemia. J Diabetes. 2011; 3(1): 29-37. doi: 10.1111/j.1753-0407.2010.00107.x.

20. Gurung S, Skalko-Basnet N. Wound healing properties of Carica papaya latex: in vivo evaluation in mice burn model. J Ethnopharmacol. 2009; 121(2): 338-341. doi: 10.1016/j.jep.2008.10.030

21. Hewitt H, Whittle $S$, Lopez $S$, Bailey E, Weaver $S$. Topical use of papaya in chronic skin ulcer therapy in Jamaica. West Indian Med J. 2000; 49(1): 32-33.

22. Jain SK. Medicinal plants. National book trust India; 1968; 12: 252-256.

23. Jayakumar R, Kanthimathi MS. Inhibitory effects of fruit extracts on nitric oxide-induced proliferation in MCF-7 cells. Food Chem. 2011; 126(3): 956960. doi: 10.1016/j.foodchem.2010.11.093

24. Khan FA, Hussain I, Farooq S, Ahmad M, Arif M, Ur Rehman I. Phytochemical Screening of Some Pakistanian Medicinal Plants. Middle East J Sci Res. 2011; 8(3): 575-578.

25. Krishna $\mathrm{KL}$, Paridhavi $\mathrm{M}$, Patel JA. Review on nutritional, medicinal and pharmacological properties of Papaya (Carica papaya Linn). Natural Product Radiance. 2008; 7(4): 364-373.

26. Vimal K, Gogoi BJ, Meghvansi MK, Singh L, Srivastava RB, Deka DC. Determining the antioxidant activity of certain medicinal plants of Sontipur, (Assam) India using DPPH assay. J Phytol. 2009; 1(1): 49-56.
27. Lim TK. Edible Medicinal and Non-Medicinal Plants. Volume 1, Fruits. 2012: 110-118.

28. Lohiya NK, Goyal RB, Jayaprakash D, Ansari AS, Sharma S. Antifertility Effects of Aqueous Extract of Carica papaya Seeds in Male Rats. Planta Med. 1994; 60(05): 400-404. doi: 10.1055/s-2006-959518

29. Lohiya NK, Kothari LK, Manivannan B, Mishra PK, Pathak N. Human sperm immobilization effect of Carica papaya seed extracts: an in vitro study. Asian J Androl. 2000; 2(2): 103-109.

30. Lohiya NK, Manivannan B, Mishra PK, et al. Chloroform extract of Carica papaya seeds induces long-term reversible azoospermia in langur monkey. Asian J Androl. 2002; 4(1): 17-26.

31. Hoareau L, DaSilva EJ. Medicinal plants: a re-emerging health aid. Electron J Biotechnol. 1999; 2(2): 301-320.

32. Mishra K, Bhardwaj R, Chaudhury NK. Netropsin, a minor groove binding ligand: A potential radioprotective agent. Radiat Res. 2009; 172(6): 698705. doi: 10.1667/RR1815.1

33. Morton JF, Miami FL. Papaya. In: Morton J (ed). Fruits of Warm Climates Creative Resource Systems Inc. 1987: 336-346.

34. El Moussaoui A, Nijs M, Paul C, et al. Revisiting the enzymes stored in the laticifers of Carica papaya in the context of their possible participation in the plant defence mechanism. Cell Mol Life Sci. 2001; 58(4): 556-570. doi: 10.1007/PL00000881

35. Oderinde O, Noronha C, Oremosu A, Kusemiju T, Okanlawon OA Abortifacient properties of aqueous extract of Carica papaya (Linn) seeds on female Sprague-Dawley rats. Niger Postgrad Med J. 2002; 9(2): 95-98.

36. Okeniyi JA, Ogunlesi TA, Oyelami OA, Adeyemi LA. Effectiveness of dried Carica papaya seeds against human intestinal parasitosis: A pilot study. J Med Food. 2007; 10(1): 194-196. doi: 10.1089/jmf.2005.065

37. Osato JA, Santiago LA, Remo GM, Cuadra MS, Mori A. Antimicrobial and antioxidant activities of unripe papaya. Life Sci. 1993; 53(17): 1383-1389. doi: 10.1016/0024-3205(93)90599-x

38. Otsuki N, Dang NH, Kumagai E, Kondo A, Iwata S, Morimoto C. Aqueous extract of Carica papaya leaves exhibits anti-tumor activity and immunomodulatory effects. J Ethnopharmacol. 2010; 127(3): 760-767. doi: 10.1016/j.jep.2009.11.024

39. Owolabi OJ, Omogbai EKI, Obasuyi O. Antifungal and antibacterial activities of the ethanolic and aqueous extract of Kigelia africana (Bignoniaceae) stem bark. Afr J Biotechnol. 2007; 6(14): 882-885.

40. Sen R. Principles and Management of Cancer. BI Publications. 2004: 1-182.

41. Ray G, Husain SA. Oxidant, antioxidant and carcinogenesis. Indian J Exp Biol. 2002; 40(11): 1213-1232.

42. Rumiyati S. Effect of protein fraction of Carica papaya L. Leaves on the expressions of $\mathrm{p} 53$ and $\mathrm{Bcl}-2$ in breast cancer cells line. Maj Farm Indones. 2006; 17(4): 170-176.

43. Shackel Ford RE, Kaufmann WK, Paules RS. Oxidative stress and cell cycle checkpoint function. Free Radic Biol Med. 2000; 28(9): 1387-1404. doi: 10.1016/s0891-5849(00)00224-0

44. Wink M. Plant breeding: importance of plant secondary metabolities for protection against pathogens and herbivores. Theor Appl Genet. 1998; 75(2): 225-233.

45. Siju, GR Rajalakshmi, Kavitha, Anju Joseph. In Vitro Antioxidant Activity of Mussaenda Frondosa. Int J Pharmtech Res. 2010; 2(2): 1236-1240.

46. Singer AJ, Clark RA. Cutaneous wound healing. N Eng J Med. 1999; 341(10): 738-746. doi: 10.1056/NEJM199909023411006

47. Singh J, Upadhyay AK, Prasad K, Bahadur A, Rai M. Variability of carotenes, vitamin C, E and phenolics in Brassica vegetables. J Food Compost Anal. 2007; 20(2): 106-112. doi: 10.1016/j.jfca.2006.08.002

48. Stepek G, Buttle DJ, Duce IR, Lowe A, Behnke JM. Assessment of the anthelmintic effect of natural plant cysteine proteinases against the gastrointestinal nematode, Heligmosomoidespolygyrus, in vitro. Parasitology. 2005; 130: 203-211. doi: 10.1017/s0031182004006225 
49. Stepp JR, Moerman DE. The importance of weeds in ethnopharmacology. $J$ Ethnopharmacol. 2001; 75(1): 19-23. doi: 10.1016/s0378-8741(00)00385-8

50. Stoilova I, Krastanov A, Stoyanova A, Denev P, Gargova S. Antioxidant activity of a ginger extract (Zingiber officinale). Food Chem. 2007; 102(3): 764-770. doi: 10.1016/j.foodchem.2006.06.023

51. Subenthiran S, Choon TC, Thayan R, et al. Carica papaya leaves juice significantly accelerates the rate of increase in platelet count among patients with dengue fever and dengue haemorrhagic fever. Evid Based Complement Alternat Med. 2013: 616737. doi: 10.1155/2013/616737

52. García-Solís P, Yahia EM, Morales-Tlalpan V, Díaz-Muñoz M. Screening of antiproliferative effect of aqueous extracts of plant foods consumed in México on the breast cancer cell line MCF-7. Int J Food Sci Nutr. 2009; 60: 32-46. doi: 10.1080/09637480802312922
53. Wang J, Yi J. Cancer cell killing via ROS: to increase or decrease that is the question. Cancer Biol Ther. 2008; 7(12): 1875-1884. doi: 10.4161/ cbt.7.12.7067

54. Wright JB, Shi L. Accuzyme ${ }^{\circledR}$ papain-urea debriding ointment: a historical review. Wounds. 2003; 15(5): 133-142.

55. Tripathi YB. Free radicals in Ayurveda. Anc Sci Life. 1998; 17(3): 158-168. 